\title{
オスマンのパリ改造計画における緑地計画の理念及び その実態について
}

\author{
佐々 木 邦 博*
}

L'idée et la réalité du système des espaces verts de Paris par Haussmann

Kunihiro SASAKI

\begin{abstract}
摘要：19世紀中葉に実施されたオスマンによるパリ改造計画には緑地計画が重要な一部門として含まれている。緑 地をその規模により三種類に区分して考え，それぞれをバランスよく市街地及びその周辺に配置した。一つのシス テムとしてとらえられていたのであり, 緑地システムの塞現においせは世界でも最も初期の例の一つであろう。そ こでこの緑地計画の理念，及び緑地がどのように利用され，社会生活に影響を及ぼしたかを考察する。
\end{abstract}

\section{1.はじめに}

1848年, フランスに挄いて二月革命が起てる。王政が 倒され, 共和政の政治形態をとる。大統領選挙の結果, ナポレオンの特にあたるルイ・フィリップが当選したの だが，彼は 1851 年にクーデタを起こし，皇帝として即位 する。自らナポレオン三世（NAPOLEON III, 在位 18 $52-70 ）$ 之称し，第二帝政を開始するのである。彼が 権力を掌握して以来害行し始めた政策の一つとしてパリ の都市改造があげられる。当時パリは中世の面影が色濃 く残る複雑に入り組んだ道からなる都市であったのだが, それを根本的に改造しょうとしたのだ。乙の計画は多岐 にわたるが, 重要な部門の一つに緑地計画がある。パリ そ緑地を組織的に配置する計画である。都市改造が進め られていく中でての計画の実現化は人気を呼ぶものとな り, パリに華やかな魅力を与えていく。この都市改造に は当時から様々な批判が行われてきたが, ての改造の中 で建設後に多大な絶賛を受け, 反対論が消滅したのは緑 地計画であった。辛辣な作家であるジョルジュ・サンド (George SAND, 1804-76) あ著作の中で新しく建 設された緑地を絶賛している程である。1) そしてての都 市改造てそが今日のパリの根幹を形成しているのである。

その結果との第二帝政期という時代にはいくつあの緑 地が造成されたのだが, 拙論ではまずこれらの緑地の概 容を把握し, 緑地全体を鳥瞰する。そして次䎲当時これ らの緑地が持った性格，特徴を見ていきたいと思う。そ こから19世紀に都市の緑地が持っていたイメージをでき るかぎり明確にしていきたいと考える。

\section{2. 緑地の概要}

ジュルジュ・ュージェンヌ・オスマン (George Eugène HAUSSMANN, 1809-91) がナポレオン三世 によりセーヌ県知事に任命されたのは 1853年のことで ある。その当時, パリ市長の職は設けられてはいなかっ たので, セーヌ県知事がパリ市長の役割を兼ねていた。 彼がこの職に就いた時, パリ改造事業の端緒はすでに開 かれていたが, 緑地関してもブローニュの森（bois de Boulogne）の改造工事が始められていた。まず最初 に計画され, 大評判となり, いわば緑地計画に先鞭をつ け, 引き続き建設される緑地に新しいイメージを供給し たのはこのブーローニュの森なのである。この森からと りあげてみたい。

ブーローニュの森の改造はオスマンの着任以前から始 められていた。担当者はナポレオン三世の父の領地であ るサン・ルー（Saint - Leu）で庭師をしていたヴァレ

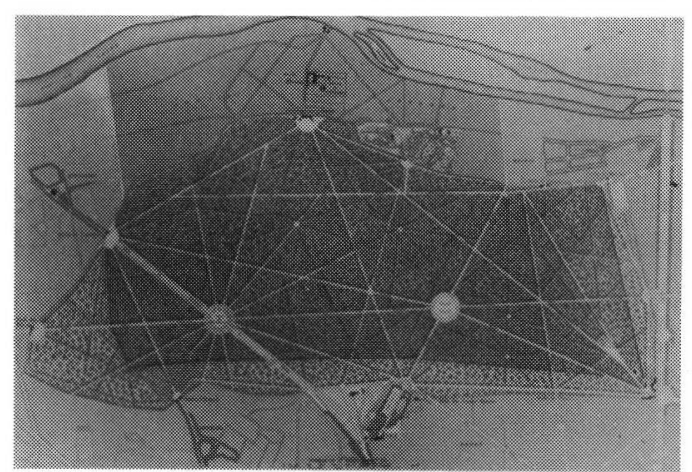

写真ー 1 改造以前のブーローニュの森

* 信州大学農学部 


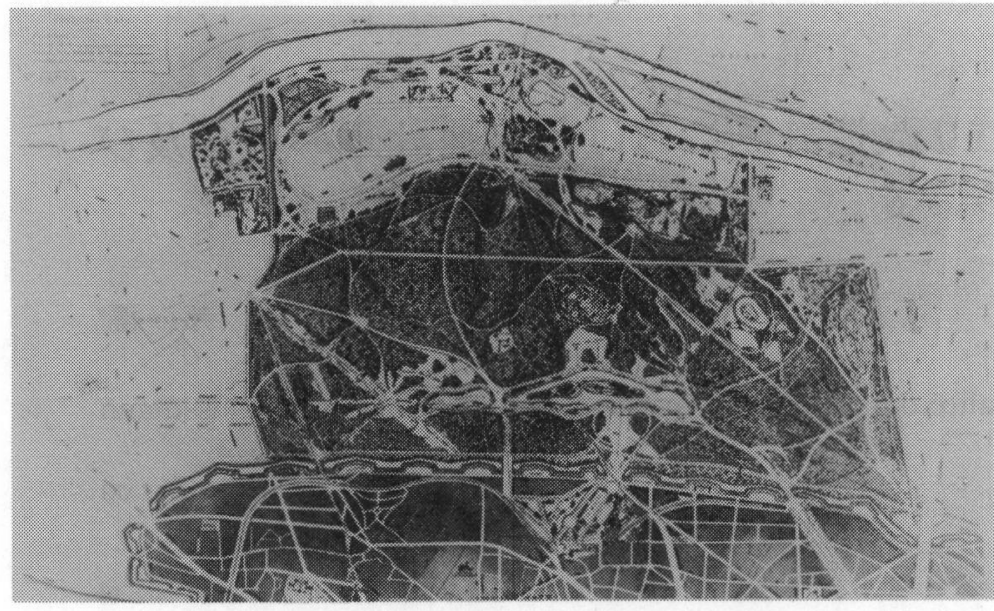

写真 -2 改造後のブーローニュの森 des races de chevaux en Fra nce), 通称ショッキークラブ協 ( Société du Jockey-Club) に貸与し, 乙の協会は競馬場を建 設した。ロンシャン競馬場である。 開場以来，競馬を見る趣味は広が り大人気を博するようになった。 またその他に，いろいろな小施設 をこじんまりと集めた有料施設, プレ・カタラン (Pré Catalan), 国外の動植物を集めた園地. 野外 スケート場・眝氷庫が建設された。 特に注目されるのはプレ・カタラ ンである。パリ市がある投資家に プレ・カタランと呼ばれている森 の中の土地を貸与し，彼は土地に
（VARÉ, ?-?）である。その時の計画はての森の東側, つまりパリの市街地よりに川及び川を巡る園路を造成す るあのであった。オスマンはまむなくこの計画の欠陥を 発見する。レベル測量の結果, 川の上流には給水できな いことが明らかになったのである。てのために工事は中 断され,ヴァレは解任される。後にオスマンはヴァレを 次のように評している。「彼はスクウェア，イギリス式 庭園, 小さな公園なら造成できるだろう。……かしし， ブーローニュの森の改造は彼の能力を越えている。」と吕 1854年にオスマンはジャンーシャルルーアドルフ・ア ルファン ( Jean-Charles - Adolphe ALPHAND, 1817-91) を呼び寄せ, 緑地の改造, 建設の責任者と した。彼は以後オスマンが県知事を解任される1869 年 までての責任者の地位を離れず，パリの緑地建設を進め ていく。

改造以前のブーローニュの森は写真 1 のように他の森 と同様に林内を直線の園路が交差していた。新たに実行 された改造案は, 川のかわりに $6 \mathrm{~m}$ の高低差を持つ二つ の池を造り，その間に滝を作って水を落とし,そしてそれ らの周囲に園路を巡らすという案である。ての案が実施 された後, 写真 2 亿見られるように森全体が改造の対象 とされ，実施された。まず直線部分には植栽され，かわ りに曲線の園路が, 馬車用. 乗馬用. 歩行者用の三種類 の用途にわけられて建設される。小川を森の中に巡らし， 池を穿ち，滝を造る，高木，低木，芝生を新たに配置す る。カフェ・レストランなどの休颕施設を作る, 森全体 をきらびやかな椢で囲う 以上か改造の主だった内容で あり, 総面積は846haに及んだ。また, 乙れは重要な点 なのだが、森の内部にいくつかの有償の施設が建設され る 森の西南部 セーヌ河畔のロンシャン (Longchamp) と呼ばれていた土地をフランス馬種改良奨励協会 (Socie d'encouragement pour l' amélioration

有料の施設を建設する。 $8 \mathrm{ha} 凹$ 状の土地を芝地とし, 花や低木で装飾したその敷地内にオーケストラのための ロトンド(丸屋根の円形の建物で、柱列で支えられ，壁は なく, 内側でオーケストラが演奏し, 聴衆はこの周囲で 音楽に耳を傾ける), ビュッフェ,ビアホール、写真館、 奇術と人形劇のための魔法の劇場, 花の野外劇場, 乳製 品店, 水遊館などを配置した。 1856 年に開業した一種 の遊園地のようなとの企画は人気を呼び. 大成功を収め たのだが，収入の不安定さや夜間の照明にかかる膨大な 出費により 2 年後にての企画はつぶれた。 1861年には パリ市にこれらの施設が移管され, その後は無料で開放 された。

ブーローニュの森の改造計画が緑地計画の中で最初の あのであり，また開園と同時に多大な人気を博し，大評 判になったゆえにてのように詳しく説明したのだが，自 然に対して孤独やロマンティシズムを求めた18世紀の散 策の場や現代 の公園とはか なり違い, 19 世紀中葉に改 造されたブー ローニュの森 はこのように 賑やかな場所 だったのであ る。

この森の改 造中. パリの 街中ではスク ウェアが造ら れる。スクウ エアとは道路

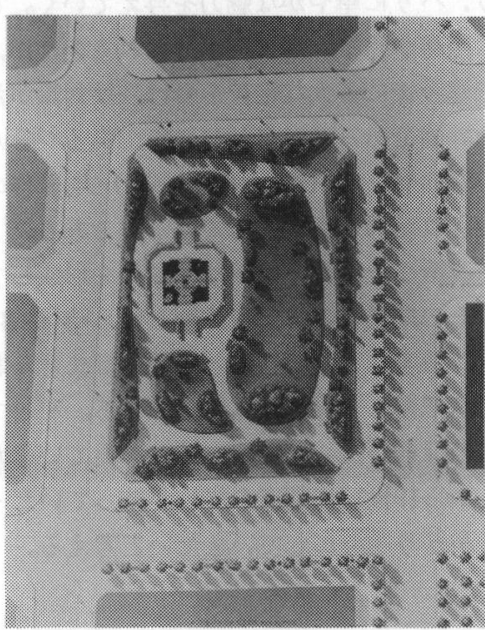

写真一 3 サン・ジャック スクウェア 
の広い交差点などに柵に囲ま れて造られた小規模の公園で あり,イギリスのスクウェア を参考にして建設されたが, イギリスと違い，一般に開放 され，誰でも利用することが できる公園である。1 1856 年 にはサン・ジャック・スクウ エア (square Saint-Jacques, $0.5 \mathrm{ha})$, 翌年には夕 ンプル・スクウェア (square du Temple, $0.75 \mathrm{ha}$ ) が建設される 両者とあ曲線 の園路之広い芝生から構成さ れて抢り, 写真 3 の上うに高 木. 低木, 草花汃配置されて

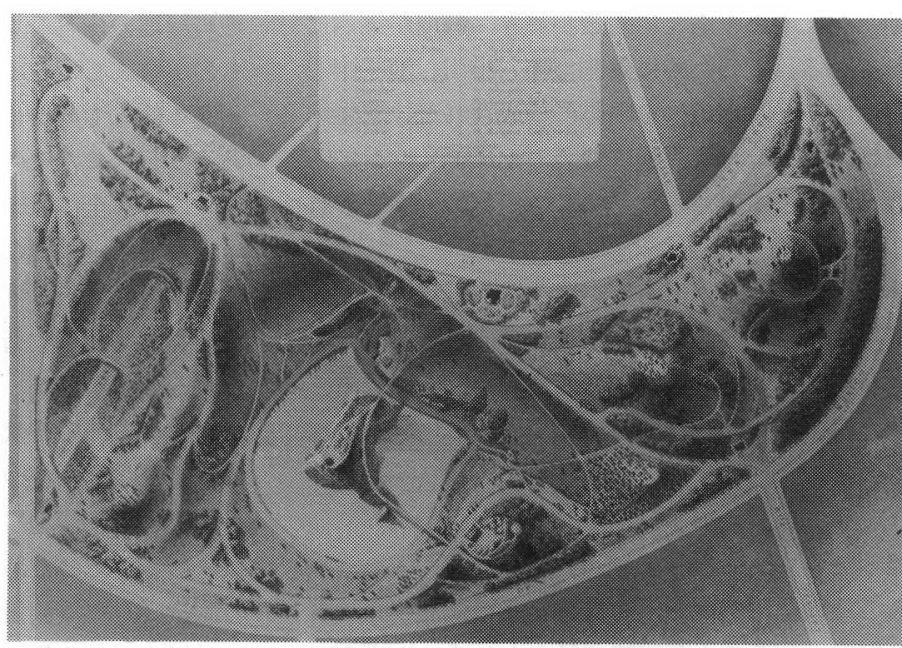

写真ー4 ビュットショモン公園 いる。タンプル・スクウェア

ではさらに池とそこに水が注ぐように岩組みされた滝が 造られた。

ブーローニュの森の改造は 1858 年に完成するが，乙 の年, パリの東側, つまりブーローニュの森と反対の側 にあるヴァンセンヌの森 (bois de Vincennes) の改造 が決定される。1860年に工事が始まり、1865 年に終 了するのだが，その内容は全体としてブーローニュの森 とよく似た構成をとっている。しかし，大きく異なる点 がある。それは総面積 901 haにのぼるヴァンセンヌの森 が二つの部分にわかれていることである。はさまれた区 域には大砲射撃演習場及びヴァンセン又城駐屯部隊演習場な よ゙があり，移転させることができなかった。さらに学校 用にも敷地を提供させられる。このようにヴァンセンヌ の森の改造はより困難であり、その内容もより地味にな ったのだが.オスマン自身もブーローニュの森の成功に およばないと述べている。

1859 年にはスクウェアが 4 ケ所で建設される。いず れも内容は前述のスクウェアと同様である。

モンソー公園（parc de Monceaux）は1778年 に王 族の一員であるフィリップ・ドルレアン（Philippe d" ORLEAN, 1747-93 ）によりパリの北西部に造られた公 園が母体である。1860年にパリ市が道路を通すために 庭園全体を取得し, その約 3 分の 1 にあたる 8.6 haを公 園に改造する。工事は翌年 1 月に開始され，9月に終了 する。なだらかな起伏が造られ，長い間枯れていた水が 流される。滝をなす岩組の中にはグロットが設けられ， ロトンドは修復された。池も同様である。この公園も優 雅な鉄柵を周囲に巡らし，門もまた鉄柵で造られている。 オスマンはこの公園を「パリで最も豪奢で, 最も上品な」 あのと述べている。

1860 年にパリ周辺の 11 の自治体がパリに吸収合併さ
れる。この結果、今日のパリ市の範囲を形成するのだが， 下町であった19区と20区のあたりに新しく公園を造成し た。採石場であり, 動物の死体を解体する作業場でああ り, また同時に屎尿捨て場でああったビュット・ショモン (Buttes Chaumont) にである。乙の計画は 1862 年 に決定され，64年に工事が始まり、難工事のために67年 にやっと完成する。乙れが面積約25haのビュット・ショ モン公園である。この区域は傾斜地にあるため, その特 徵をいかして芝地や樹林, 園路が写真 4 のように配置さ れ.山岳地域の風景の様相が形成された。この公園のシ ンボル的な存在は池の中に塔のように高くそびえたつ島 である。岩を積み重ねた，高さ $20 \mathrm{~m}$ を越える人工物であ り，頂上にはロトンドをのせ，橋が二本かけられている。 付近には採石場の跡を利用してグロットがつくられ，ま た落差が35mあるカスカードあ造られている。乙れ程の 起伏にもかかわらず，主要な園路は馬車が通れるように 設計されている。

合併によるパリ市域の拡大は新しい区にスクウェアを 建設することを促がす。1 1860 年以降オスマンの解任ま で16のスクウェアが造られたが, その中の 6 ケ所のスク ウェアは新しい区に建設された。その内容は前述したス タイルを踏襲しているが, アール・エ・メティエ・スク ウェア (square des Arts et Métiers) だけが異な っている。樹木を五ノ目型に植栽し, シンメトリーの構 成からなっているのである。1869年のオスマンの解任 の時にはさらに三ケ所のスクウェアが建設, 計画中であ った。

さて, ビュット・ショモン公園の建設終了後, モンス リ公園 (parc de Montsouris) の建設が始まる。パリ の南部に位置する 15.8 ha の建設は長びき, 1878 年に やっと完成する。乙ともビュット・ショモン公園と同様 
に傾斜地だが，中央を南北に鉄道が貫き，敷地が東西に 二分されている。てのために東側は滝，小川．池を中心 に, 西側は広々とした芝生を中心に構成された。芝生地 の高台には 1867 年パリ万国博覧会のたにチュニジア総 督の宮殿を模放して建てられたチュニジア館が移筑され た。

以上が第二帝政期に創造あるいは改造された緑地であ り，ほぼ年代順に亚べてある。乙れらの他にも・幅の広 い並木道が建設されているし, また幅 $20 \mathrm{~m}$ 以上の道路に は並木道となるように樹木を植栽するという緑化政策が行 なわれている。

\section{3. 緑地のシステム化}

これらの緑地全体を見わたすなら，面積により三つの タイプに区分されることが明膫に見てとれる。まず 900 ha前後のブーローニュの森とヴァンセン又の森が一つの グループを構成し，次にモンソー公園. ビュット・ショ モン公園，モンスリ公園と， 8.6 haから 2.5 haにかけての 公園がグループを形成している。そして 0.2 haから $2.5 \mathrm{ha}$ のスクウェアがまたグループをなしている。てのように， 面積と数という点から見るなら, 森一公園一スクウェア 亡いう序列がつけられ, さらにその後に並木道がつけ加 わる。つまりヒエラルキーを持ったシステムを構成して いることが容易に見てとれるのである。これを第一の特 徵とすると, 第二の特徴は緑地の位置関係にある。図一 1 はオスマンが創造あるいは改造した緑地を地図上にお としたものである。まず広大な二つの森がパリの東西に 位置し, 中規模の公園が北西, 北東, 南にバランスよく 置かれている。そして規模が小さいスクウェアは市内に 空地ができしだい建設された。このように緑地はパリの 中に均等にちりばめられているのであり, 都市内のあら ゆる地域の平均化を狙っていると言える。乙の意四から
逆に緑地の内容を見ていくなら，緑地はなるべく同様の あのが望ましくなる。てれが緑地のデザインにおいてイ ギリス的なものがほぼ一律に使わ机ている理由の一つで あろうし，またてのことはフランソワーズ・ショエ教授 が「均一な全体性を創出するための緑地の中性化」と呼 んでいることに他ならない。 り緑地のシステムは成りたっているのである。

それでは都市改造の他の計画と緑地計画はどう関連し ているのだろうか。まずオスマンによる都市改造の特徵 だが，彼以前の時代のパリに見られるような市街地の周 縁に新たな区画をつくるという手法を採らず，中心部か ら周縁まで市街地を全体的に把握し，改造しようとした 点にある。そのために彼が最初に指示したのはパリ全体 の測量（レベル測量む含む）であった。これはパリにお いて初めての測量であり、てれが根本的な都市改造を可 能にしたのである。またての結果，ブーローニュの森の 最初の計画の欠陥が明らかになったのである。オスマン が進めた計画は、一口で言うなら，中世的な市街地を払 拭し，新しい街を創万うとするあのだった。そのために まず, 幅の広い直線の街路を市内中に巡らす街路計画が ありそそして全く不十分であった上・下水道を完備しょ うという計画があった。これら二つの計画に緑地計画を 加えた三つの計画が都市改造の主要な軸となっているの である。街路計画, 上・下水道計画にもそれぞれ街路の 幅の違い，水道管の大きさの違いが計画されている。つ まり．その機能上、ヒエラルキーを持ったシステムとし て考えられ，造られているのである。オスマン自身はて の点をレゾー（réseau：網という意味）という言葉で説 明しているが7? これは現代におけるシステムという単語 と対応させて考えてよい。また，位置関係だが，乙れら の二つの計画も全市内を均一化するように計られている のである。 このととは．乙の三つの計画が，互いに関連
図ー1 オスマンにより建設された緑地の配置図

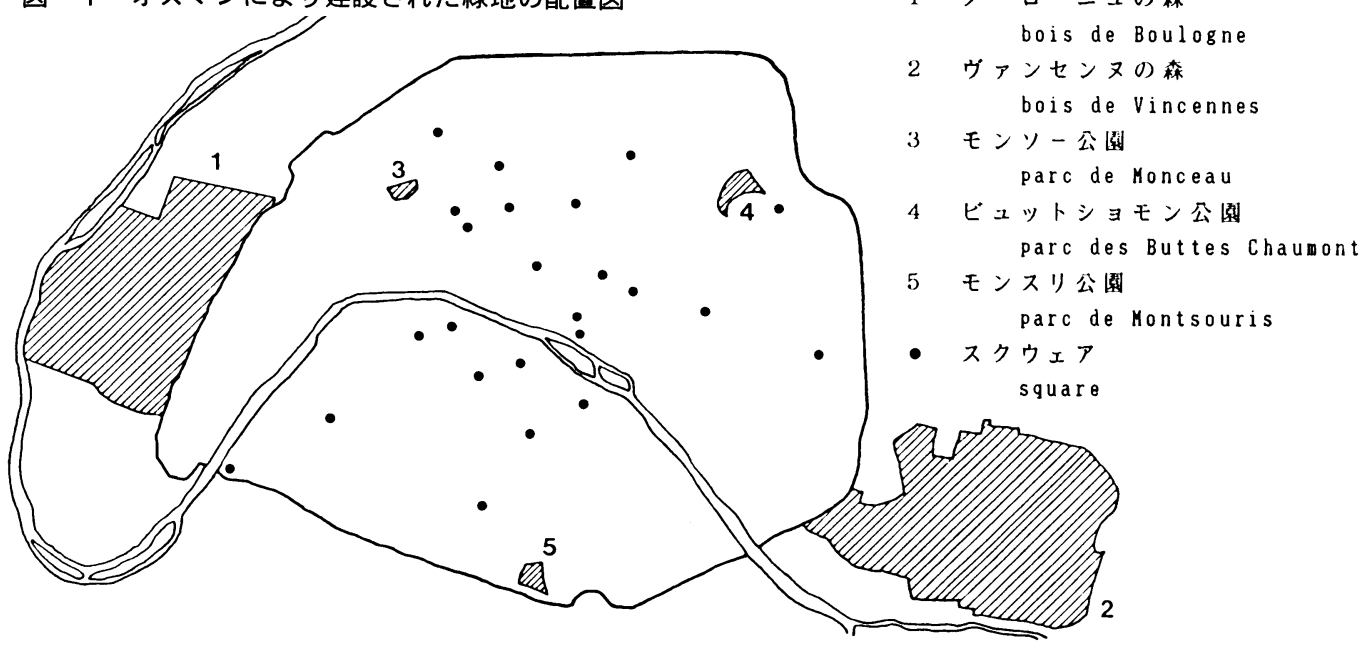


を持たせながら，同等に計画されたてとを物語っており， 緑地計画はオスマンによるパリ改造に打いて他の二つの 計画之同程度の重要性を与えられていたてとをも物語っ ているのである。

\section{4. 緑地のもった意味}

さてての緑地計画の目的はどんな点にあったのだろうか。 そのためにまず19世紀に抢ける都市の状態を見ていきたい。

19世紀に入るとフランスでは産業革命が進行していく。 都市には工場が建ち, 農村から人々が労働者として都市 に集まってくる。パリの人口は1801年には約55万人だ ったのだが，1846 年には 105 万人に達しており，ほぼ 二倍に膨らんでいる。人口増加の傾向は大規模な都市改 造が行われる第二帝政期に扔いても続いていく。急激な 人口の集中・増大は当然のことながら都市の環境の少悪 化を招き, 特に衛生面の問題が深刻になる。そしてまた 産業革命の進行は, 原料及び大量生産物の輸送, 労働者 の往来という点で, 細く曲りくねった道からなる中世的 な都市を根本的に変えていくのをよぎなくするのである。 パリ改造計画は19世紀前半にもたてられ，何本かの街路 が建設されたが, ${ }^{9)}$ 根本的な改造には程遠く, 問題を解決 するにはいたらなかった。これらのととがナポレオン三 世とオスマンに都市改造を行わせる源動力となったので ある。

この緑地計画の目的なのだが，乙の点についてナポレ オン三世とオスマンの間に若干の相違が見られる。ナポ レオン三世は緑地の存在意義に対して道徳的効果と衛生 状態の改善を上げているが, オスマンは衛生状態の改善 しか考えてはいない。10）19世紀前半のパリは上・下水道 が未発達であり，街路は狭险で入り組み、ゴミや污物が あふれ，悪臭が漂っていた。1830年代にはコレラの大 流行にみまわれ 約 18000 人ぐらいの人々が死亡してい る。衛生状態の改善はこの流行以前から主張され続けて きたてとなのである。オスマンが緑地建設を押し進めた のはあくまでもての改善の一環としてなのであり、悪臭 のない，きれいな空気を吸える場所を建設するのが目的 だったのである。そしてナポレオン三世とオスマンの相 異は, 後者がより徹底して現実に即して問題を考えてい たととによるのである。

このように衛生状態改善のための場所としての認識が 第一にあるのだが，一方で緑地を訪れる人々がその緑地 をどのように利用していたのかという問題が同時にでて くる。緑地はその存在そのものに意義があるばかりでは ない。都市内に生まれた全く新しい場所がどう使われた かという点に関心がもたれるのは当然のことである。

この時代によく使われた言葉の一つにプロムナードゥ (promenade)がある。元来. 散歩や散策の意味で使わ れていたし，現在でもそうなのだが、次に第二の意味と
して散歩の道筋，散策の場所を示すようになる。アルフ アンは自らが担当した緑地を解説し、その詳細な資料を 添えた本を出版しているが，その本のタイトルに「プロ ムナードゥ・ドゥ・パリ」 (Promenade de Paris : 「パリの散歩道」という意味）という名をつけている。 彼は緑地総体をプロムナードゥとしてとしてとらえてい たのであり散歩を楽しむ場所と認識していたのである。 これが行政の立場からみた緑地の姿なのであった。

とてろで緑地のデザインに関してだが，写真 $2 ， 3$, 4 をもう一度見ていただきたい。なだらかな起伏のある 芝地, 曲りくねった川, 曲線の園路など, 一足先に造ら れたイギリスの公園のデザインを採り入れている。そし てさらに，それはラウドンの主張したガードネスクのフ ランスへの適応にすぎないとか，フランスのジュラ（Jura）やヴォージュ（Vosges）地方の谷の景観に似て いるという指摘もなされている。11) しかし一見しただけ であある理想化された自然景観を具体的に作りあげてい ることは明白であるし，現実以上の，つまり現実にはな い景観をつくっているのである。緑地内では芝地の周辺 には低い半円形の柵がおかれ，立入禁止上なっているこ とが多いが，乙の点も景観を重視した結果のあらわれで ある。すなわち, 芝地を利用する, 使うことよりも芝地 を含む空間を眺めるてとの方に，つまり視覚にうったえ る景観の方に重点を拈いているのである。しかし，一方 でこの景観を生み出すにはある程度の広さを必要之する。 起伏をもたせた地面をうまくいかすにはある程度まとま った面積が必要だが，スクウェアでは十分な面積を与え るとよができない。ゆえに起伏がないか，もしくは非常 に穏やかなものになっている。バティニョル・スクウエ ア（square des Batignolles，1.7 ha）には滝, 小川, 池が形造られ，水が流されている。地面にはある程度の うねりがあり，人気のあるスクウェアなのだが，よくよ く注意して眺めるとちょっとしたアンバランスに気がつ く。園路により区切られているうねりのある小区画と平 担である幅広い園路との間にバランスがとれていないの

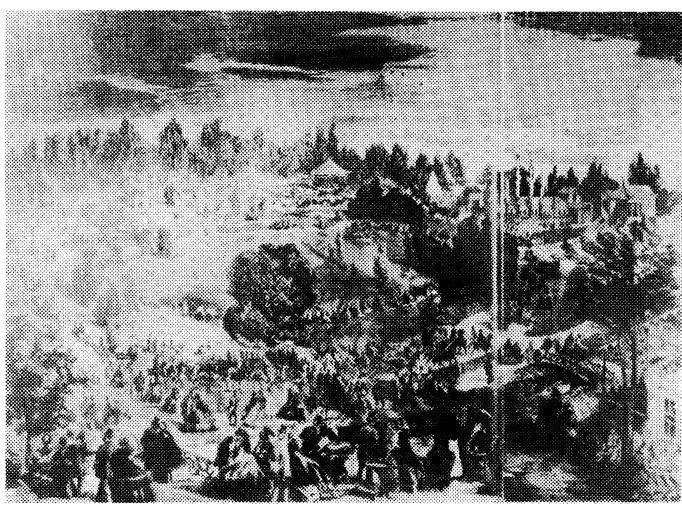

写真 -5 改造後のブーローニュの森の一風景 
である。園路を幅の方向に傾斜させると当然ながら歩き ゔらく，乙の方向には傾斜させられない。乙の幅が傾斜 のある小区画に対して相対的に大きく目立ち, アンバラ ンスを引き起てしているのである。つまりほとんどの緑 地に採用されたての種のデザインは森や公園ではうまく 適合したが，スクウェアに揖いては小面積のためにその 特徴をうまく発揮できていない。乙れが散歩する場とし ての緑地のデザインの特徴なのである。

さててれらの緑地の利用に関してだが，プロムナード ウとみなされ，散歩に利用されることはすでに述べた通 りである。次の問題は、それがどのような散歩なのか, その雾用気なのである。当時のプレ・カタランを描いた 絵 写真 5 によく表机てるが，散歩している人々はう きうきと楽しそうな表情をしており，陽気に談笑してい る。現代のように休息を求めて公園に行っているような 様子ではない。最初に建造された緑地，ブーローニュの 森には森や滝, 小川, 池, 芝生が造られたばかりではな く，競馬場やプレ・カタランなど娛楽施設があいついで 建設されている。森の内部は決して静寂な空間ばかりが 存在していたのではなく，それらの施設に人々が集まり， 混雑する賑やかな空間を内包していたのであり，むしろ まるで遊園地と言ってもよいようなてのイメージがブー ローニュの森のイメージを代表していたのである。パリ 市民全体のために構想された森なのだが，週末以外に労 働者の利用は望みようがなく，従って平日は富裕な階級 がなかば独占的に利用する場となっていく。ての結果, この森は次第に金持ちと物見高い外国人であふれ，富を 見せびらかす場所，彼らが集まる場所とむなっていくの である。12）しかも緑地内に建ついろいろな建造物が全く 新しい雾囲気づくりを行っている。門番の建物やレスト ランなどの園内の建築はすべて建築家ダヴィウドゥが設 計を担当しているが，イギリスのコッテイジのスタイル やベイウィンドウを積極的に採り入れている。 通常のフランスの雾用気とは異った雾井気を森に䁔し出 しているのである。しかも森は優雅にデザインされた鉄 柵により外の世界と区分されている。つまり改造された ブーローニュの森は単なる「美しい自然景観が造り出さ れた空間」にすぎないのではない。その外部から切り離 され，異化された空間なのである。そしてての森の改造 の目的を考えるなら，どれ程自然景観を強調しようとて の森は都市の巨大化により産み出された都市の装置なの であり、都市文化の産物なのである。あるいは, 緑地内
部の雾用気、人々の振舞いを考えるなら，乙の森は「都 市という大劇場の内部にある特別な劇場」 ${ }^{14)}$ とも言える のである。そしててのような見るせ見られるという関 係以外に，いろいろ造り出された施設を楽しむという面 を考えるなら，乙の森は娛楽施設という面を見せてくれ るのである。

\section{5. おわりに}

ブーローニュの森の改造以来, 公園やスクウェアなど の一連の緑地建設が進んでいくが，それと同時にブーロ 一ニュの森のイメージがてれらの緑地のイメージの形成 に強く影響し，伝播していく。他の緑地もブーローニュ の森のイメージを引きずった視線で見られていくのであ る。つまりこの森の改造により緑地全体のイメージが形 成されたと言っても過言ではない。緑地が建設されてい くにつれてプロムナードゥは習慣化していき，広がって いく, 一連の緑地建設は都市の衛生状態の改善にとどま らず, 生活様式の一部を変えていく媒体となったのである。

\section{引用文献}

1) George SAND ( 1867): La rêverie de Paris In Paris Guide. Librairie International. pp 1196 - 1203

2) George Eugéne HAUSSMANN (1890): Mémoire du baron Haussmann. vol 3.p 122

3) Jean Charles Adolphe ALPHAND ( 1867 - 73) : Les promenades de Paris. J. Rothschild. p90

4) J.E.HAUSSMANN：前掲書 p 210

5) J。E. HAUSSMANN：前掲書 p 233

6) Françoise CHOAY (1975): Haussmann et le systéme des spares verts parisiens, In Revue de l'Art n.29. p 90

7) J.E.HAUSSMANN : 前掲書 p 93

8) F.CHOAY : 前掲書 p 93

9) Pierre LAVEDAN (1975): Nouvelle Histoire de Paris. Hachette. pp 327-412

10） J.E。HAUSSMANN：前掲書 p 240

11) F.CHOAY：前掲書 p 96

12) J.E.HAUSSMANN：前掲書 p 225

13) Théodore VACQUER (1860) : Le bois de Boulogne architecturtural. pp 3-12

14） F。CHOAY：前掲書 p 94

Résumé : Pendant l'époque du Second Empire (1852-70), Paris fut transformée par Haussmann, préfet de la Seine. Il réalisa trois systèmes hierarchisés : voie, eau (adduction et égout), espace vert. Le rôle principal de ce dernier système était l'amélioration de la hygiène comme Haussmann l'insista. Mais ce système joua aussi le rôle pour avoir l'habitude de se promener, et de se divertir aux espaces verts, c'est-à-dire pour changer la vie urbaine. 